\title{
Psychometric properties of the resilience scale in Mexican patients with chronic hemodialysis
}

\author{
Abel Lerma, ${ }^{1}$ Gabriela Ordónez, ${ }^{2}$ Lubia Mendoza ${ }^{3}$ Elihud Salazar-Robles ${ }^{4}$ Jesús Rivero, ${ }^{5}$ Emmanuel Pérez-Granados, ${ }^{3}$ \\ Héctor Pérez-Grovas, ${ }^{5}$ Patricia Ruiz-Palacios, ${ }^{2,6}$ Armando Ibarra, ${ }^{2}$ Claudia Lerma ${ }^{7}$
}

Instituto de Ciencias de la Salud, Universidad Autónoma del Estado de Hidalgo, Pachuca, México.

2 Clínica de Hemodiálisis, Soporte Renal Integral, Ciudad de México, México.

${ }^{3}$ Clínica de Hemodiálisis Juan Pablo II, León de los Aldama, México.

${ }^{4}$ Clínica de Diálisis La Loma, Nuevo Vallarta, México.

5 Departamento de Nefrología, Instituto Nacional de Cardiología Ignacio Chávez, Ciudad de México, México.

- Centro de Diagnóstico Ángeles, Ciudad de México, México.

7 Departamento de Instrumentación Electromecánica, Instituto Nacional de Cardiología Ignacio Chávez, Ciudad de México, México.

\section{Correspondence:}

Claudia Lerma González

Departamento de Instrumentación Electromecánica, Instituto Nacional de Cardiología Ignacio Chávez.

Juan Badiano 1, Col Sección 16, 14080 Tlalpan, Ciudad de México. Phone: +52 (55) 5573 - 2911, ext. 1386

Fax: +52 (55) $5573-0926$

Email: dr.claudialerma@gmail.com

Received: 17 July 2018

Accepted: 3 June 2019

Citation:

Lerma, A Ordónez G Mendoza, L., Salazar-Robles, E., Rivero, J., Pérez-Granados E., Pérez-Grovas, $\mathrm{H}$. Ruiz-Palacios, P., Ibarra, A., \& Lerma, C. (2019). Psychometric properties of the resilience scale in Mexican patients with chronic hemodialysis. Salud Mental, 42(3), 121-129.

DOI: $10.17711 /$ SM. $0185-3325.2019 .016$

\begin{abstract}
Introduction. Resilience consists of a series personalized skills to cope with adverse situations and overcome them, and even emerge strengthened. Resilience in patients with chronic renal insufficiency (CRI) treated with hemodialysis $(\mathrm{HD})$ has been evaluated with general questionnaires that are not specific for this population. Objective. To evaluate the psychometric properties of a resilience questionnaire in patients treated with chronic HD. Method. The study included 280 patients with CRI (aged 18 to $85,44 \%$ women) treated with HD for at least two months in six hemodialysis units in Mexico, who completed Beck's depression and anxiety inventories, an inventory of cognitive distortions, and the Mexican Resilience Measurement Scale (RESI-M). Results. Owing to the duplication of more than one factor, two of the 43 items were eliminated in the exploratory factor analysis. We confirmed five factors that explained $63.4 \%$ of the total variance, with a Cronbach's alpha of .96 (the alpha ranges in the five factors from .85 to .95). The confirmatory analysis showed a theoretical structural model that fits the empirical data in an acceptable, balanced, and parsimonious way. The five factors correlate positively with each other and negatively with anxiety and depression symptoms and distorted thoughts. Discussion and conclusion. The RESI-M scale is valid and reliable for assessing resilience in patients treated with chronic HD. Resilience factors evaluated with RESI-M are a potential therapeutic target to reduce depression and anxiety symptoms in these patients.
\end{abstract}

Keywords: Hemodialysis, chronic renal insufficiency, psychological resilience, depression, anxiety, reliability.

\section{RESUMEN}

Introducción. La resiliencia consiste en una serie de habilidades personalizadas que sirven para afrontar situaciones adversas y superarlas, e incluso salir fortalecido. La resiliencia en pacientes con insuficiencia renal crónica (IRC) tratados con hemodiálisis (HD) se ha evaluado con cuestionarios generales, no específicos para esta población. Objetivo. Evaluar las propiedades psicométricas de un cuestionario de resiliencia en pacientes tratados con HD crónica. Método. Se incluyeron 280 pacientes con IRC (edad 18 a 85 años, $44 \%$ mujeres) tratados con $\mathrm{HD}$ al menos dos meses en seis unidades de hemodiálisis en México, que respondieron los inventarios de depresión y ansiedad de Beck, un inventario de distorsiones cognitivas y la escala de medición de resiliencia con mexicanos (RESI-M). Resultados. Por duplicidad en más de un factor, se eliminaron dos de 43 reactivos en el análisis factorial exploratorio. Se confirmaron cinco factores que explicaron $63.4 \%$ de la varianza total, con alfa de Cronbach de .96 (el alfa en los cinco factores va de .85 a .95). El análisis confirmatorio mostró un modelo estructural teórico que se ajusta aceptable, equilibrada y parsimoniosamente a los datos empíricos. Los cinco factores se correlacionan positivamente entre ellos y negativamente con los síntomas de ansiedad, depresión y los pensamientos distorsionados. Discusión y conclusión. La escala RESI-M es válida y confiable para evaluar resiliencia en pacientes tratados con HD crónica. Los factores de resiliencia evaluados con la RESI-M son un blanco terapéutico potencial para disminuir los síntomas depresivos y ansiosos en estos pacientes.

Palabras clave: Hemodiálisis, insuficiencia renal crónica, resiliencia psicológica, depresión, ansiedad, confiabilidad. 


\section{INTRODUCTION}

Chronic kidney disease (CKD) negatively impacts patients' lives in various spheres (social, economic, psychological, work, and in the family nucleus) (Cukor, Cohen, Peterson, \& Kimmel, 2007). These psychopathologies are most common in patients with CKD in hemodialysis-based substitute treatment, and impact their morbi-mortality (Cukor, Coplan, Brown, Friedman et al., 2008; Cukor, Rosenthal, Jindal, Brown, \& Kimmel, 2009).

Resilience is defined as a person's ability to develop healthily and successfully, despite being exposed to situations that jeopardize his/her integrity (Cukor et al., 2009). When resilience is seen from this positive approach, it is possible to understand the close link between health psychosocial adaptation and successful recovery from adverse experiences (Cabanyes Truffino, 2010), particularly illness, due to the presence of protective factors learned in childhood (Rodriguez-Piaggio, 2009). Resilience makes it easier for patients to perceive a low degree of physical interference and improve their future health perspectives, since they remain more optimistic, stave off illness, and perceive more control over their behavior and emotional states, which in turn encourages their treatment adherence and improves their overall quality of life (Vinaccia \& Quiceno, 2011). Conversely, various sustained, unresolved psychosocial stressors in kidney patients may be associated with low resistance or allostatic burden, when applied to health and illness settings, particularly CKD (Cukor et al., 2007). For example, it is known that the time of diagnosis of an illness is inversely related to resilience (Quiceno \& Vinaccia, 2012), and that depression and anxiety symptoms are associated with certain distorted thoughts in patients with CKD (Lerma, Salazar, Perez-Grovas, Bermudez et al., 2012). It is also know that modifying these distorted thoughts makes it possible to reduce depression and anxiety symptoms and improve the quality of life of these patients (Lerma, Perez-Grovas, Bermudez, Peralta-Pedrero, Robles-García et al., 2017). Multicultural studies of kidney patients point to the need to explore their resilient response from the context of their ethnic-family origin (White, Bichter, Koeckeritz, Lee, \& Munch., 2002). In transplant situations, resilience is associated with aspects of positive or negative emotional adjustment, depending on patients' perception of the disease (guilt, fear, gratitude, physical limitation, independence) (Schipper, Abma, Koops, Bakker et al., 2014), as well as social support, confidence, self-esteem, devaluation, and self-efficacy (Tong, Cheung, Nair, Kurella et al., 2014).

Against this background, it is important to be able to reliably measure resilience in this population with CKD, since it has been evaluated using questionnaires in Spanish in other non-Mexican populations (Vinaccia et al., 2011). There is also a questionnaire to evaluate resilience that has been validated in Mexican population as a whole (Palo-
mar-Lever \& Gómez-Valdéz, 2010), but there is no information to date on its validity or reliability in the specific context of patients in chronic hemodialysis.

Nor have researchers evaluated whether resilience factors in kidney patients are associated with depression or anxiety symptoms, or their distorted thoughts. Having a valid, reliable questionnaire to assess resilience in this population would make it possible to identify the relationship between resilience and the development of depression and anxiety and key clinical repercussions (such as morbidity, hospitalizations, and premature mortality). Likewise, a reliable evaluation instrument would make it possible to test the effects of potential therapeutic interventions that include resilience as a modifying variable that prevents or reduces the depression and anxiety symptoms of kidney patients.

The objective was to evaluate the validity and reliability of a psychological instrument to measure the resilience of Mexican patients diagnosed with chronic kidney disease under treatment with hemodialysis, and to evaluate the correlation between resilience factors and depression and anxiety symptoms and distorted thoughts.

\section{METHOD}

\section{Study design}

This was an observational, prospective, cross-sectional study.

\section{Participants}

The study included a non-probabilistic sample of 280 patients with CKD in renal replacement therapy by hemodialysis for at least two months. They were aged between 18 and 85 , of both sexes, with any etiology of their CKD or comorbidity (with the exception of any psychiatric disorder that was documented in their files or which had a prescription for psychiatric pharmacological treatment).

\section{Location}

The sample was obtained from six hemodialysis units in four states in Mexico: Mexico City (Comprehensive Renal Support, $19=6.8 \%$, CEDIASA, $102=36.4 \%$, Ignacio Chávez Instituto Nacional de Cardiología, $21=7.5 \%$ ), León, Guanajuato, $68=24.3 \%$; Mazatlán, $45=16.1 \%$; Puerto Vallarta, $25=8.9 \%$. Participants were recruited between March and August 2015 and the evaluation was undertaken between September and December 2015.

\section{Instruments}

Resilience was evaluated through a questionnaire incorporating items from two foreign instruments adapted and 
validated for the Mexican population (Palomar-Lever et al., 2010). The Mexican questionnaire included 43 items with a Likert-type scale measuring the following resilience factors: strength and self-confidence, social competence, family support, social support, and structure. Two hundred and seventeen members of the general public participated in the Mexican validation of the resilience questionnaire, which obtained a Cronbach's alfa of .936. Depression and anxiety symptoms were evaluated using Beck's Depression Inventory (BDI) and Beck's Anxiety Inventory (BAI), which included 21 items each to measure somatic and cognitive anxiety and depression symptoms respectively (Beck, Epstein, Brown, \& Steer, 1988; Beck, 2006), both instruments having previously been validated in the Mexican population (Beck et al., 1988; Robles, Varela, Jurado, \& Páez, 2001; Torres-Castillo, Hernández-Malpica, \& Ortega-Soto, 2012). Distorted thoughts were evaluated using a 30-item instrument developed for patients with CKD (Lerma et al., 2012), which comprises four factors: catastrophism, dichotomous thinking, intrinsic perfectionism, extrinsic perfectionism, and negative self-labeling. In a sample of 255 patients with CKD, the following Cronbach's alpha were obtained: .92 for BDI, .92 for BAI, \& .936 for the distorted thoughts instrument (Lerma et al., 2012; Lerma et al., 2017).

\section{Procedures}

The clinical data and demographic information of each patient selected to participate in the study were identified and the psychological instruments delivered. Each patient was shown how to answer the self-administered questionnaires and care was taken to ensure they had understood and answered each of the questions. In the case of patients who were unable to read and write or who had some form of visual or motor disability, the survey implementer read the items in the instrument and noted the respondent's answers. The material obtained was then submitted to the principal investigator of the project for analysis.

\section{Statistical analysis}

Validation of the scale was carried out through an exploratory factor analysis (EFA) with the following steps: (i) compare the discrimination capacity of each item using the Student's t-test, (ii) evaluate the directionality of the items by cross-tables, (iii) evaluate internal reliability using Cronbach's alpha, (iv) identify factors through factor analysis using the Varimax method, (v) determine the usefulness of the structure of the components by means of the sample adequacy index and the Bartlett sphericity test.

Next, a confirmatory factorial analysis (CFA) of the first order was carried out using the maximum likelihood (ML) method, which assumed a multifactorial model with five domains or latent factors with covariance among the measurement errors. The following procedures suggested by Byrne were used to estimate the structural equations model (Byrne, 2010); AMOS 23 program was used (IBMSPSS, USA) (Arbuckle, 2012). Several indices were estimated: $\mathrm{X}^{2}(\mathrm{CMIN})$ and the ratio of $\mathrm{X}^{2} /$ degrees of freedom (CMIN/gl) as measures of parsimony; the Goodness of Fit Index (GFI) and its complements; the Adjusted Goodness of Fit Index (AGFI) and the Tucker-Lewis Index (TLI) and the Comparative Goodness of Fit Index (CFI), which is a better indicator for samples of over 200 (Byrne, 2010; U11man, 2006); and the Root Mean Square Error of Approximation (RMSEA).

Finally, the association between resilience factors and depression and anxiety symptoms and distorted thoughts was evaluated by calculating Pearson's correlation. The statistical analysis was undertaken using SPSS 15.0. A value of $p<.05$ was considered significant.

\section{Ethical considerations}

The protocol was approved by the Bioethics and Research Committees of the Instituto Nacional de Cardiología Ignacio Chávez (project number 10-699). Each participant was informed of the nature of the study, agreed to participate, and signed a consent form.

\section{RESULTS}

The study included 280 patients who had been in hemodialysis for some time (median [25th -75 th percentile] $)=33$ (16 - 50) months. Patients were aged between 18 and 85, $40 \%$ of whom had diabetes mellitus. The main occupations were: retired or unemployed $(33 \%)$, housewife $(28 \%)$, or employee (17\%). Educational attainment was as follows: secondary (66\%), basic $(21 \%)$, and university (11\%) education. The respondents' marital status was as follows: $39 \%$ lived alone (single, widowed, divorced), while $61 \%$ are partnered (married or living with their partners).

\section{Exploratory analysis}

All the items showed a capacity for discrimination (Student's $t$ test, $p<.001)$. The survey implementers checked that there were no empty boxes and the corresponding directionality of the data in the cross tables for each item. Table 1 shows the result of the factor analysis. Out of the original questionnaire with 43 items, items 19 ("When I'm not well, I know things will improve") and 29 ("I enjoy being with my family") were eliminated because they duplicated more than one factor. Five factors were obtained: strength and self-confidence (18 items), social competence ( 8 items), family support (5 items), social support (5 items), and structure (5 items). All the items had factor loads between .547 and .838 . 
Table 1

Distribution of resilience items in 280 patients with chronic kidney disease in hemodialysis treatment Results of factor analysis with orthogonal rotation. The numbers represent the factorial load

\begin{tabular}{|c|c|c|c|c|c|}
\hline \multirow[b]{2}{*}{ Items } & \multicolumn{5}{|c|}{ Factors } \\
\hline & SSC & $S C$ & $F S$ & SS & STR \\
\hline \multicolumn{6}{|l|}{ Factor 1 - Strength and self-confidence } \\
\hline 3 I am a strong person. & .727 & .209 & .082 & .197 & .159 \\
\hline 11 I think I will be successful. & .715 & .217 & .239 & .013 & .208 \\
\hline 14 My future looks good. & .673 & .189 & .293 & -.056 & .179 \\
\hline $8 \mathrm{I}$ am proud of my achievements. & .672 & .245 & .143 & .258 & -.003 \\
\hline 12 I know how to achieve my goals. & .655 & .123 & .202 & .124 & .292 \\
\hline 7 I strive to achieve my goals. & .650 & .114 & .257 & .196 & .236 \\
\hline 10 Believing in myself helps me overcome difficult moments. & 632 & .301 & .210 & .253 & .016 \\
\hline 16 I'm satisfied with myself. & .622 & .326 & .177 & .028 & .110 \\
\hline $\begin{array}{l}1 \text { What has happened to me in the past makes me feel confident I } \\
\text { will be able to cope with new challenges. }\end{array}$ & .612 & 190 & -.005 & .027 & .233 \\
\hline 13 Whatever happens, I will always find a solution. & .598 & .207 & .084 & .226 & .153 \\
\hline 5 I have control of my life. & .596 & .272 & .170 & .273 & .193 \\
\hline 4 I know very well what I want. & .593 & .372 & .084 & .234 & .174 \\
\hline 2 I know where to seek help. & .588 & .241 & -.069 & .060 & .165 \\
\hline 9 I know I have skills. & .588 & .261 & .129 & .139 & .193 \\
\hline 6 I like challenges. & .569 & .208 & .162 & .250 & .311 \\
\hline 15 I know I can solve my personal problems. & .566 & .256 & .210 & .119 & .186 \\
\hline 18 I trust my decisions. & .564 & .350 & .157 & .145 & .312 \\
\hline 17 I have realistic plans for the future. & .547 & .128 & .244 & -.123 & .374 \\
\hline \multicolumn{6}{|l|}{ Factor 2 - Social competence } \\
\hline 21 It is easy for me to establish contact with other people. & .211 & .838 & .150 & .023 & .057 \\
\hline 22 It's easy for me to make new friends. & .287 & .798 & .125 & -.023 & .141 \\
\hline 20 I feel comfortable with other people. & .240 & .779 & .018 & .045 & .094 \\
\hline 23 It's easy for me to have good conversation topics. & .217 & .767 & .048 & .130 & .143 \\
\hline 26 I enjoy being with other people. & .334 & .708 & .126 & .172 & .094 \\
\hline 27 I know how to start a conversation. & .295 & .701 & .164 & .222 & .152 \\
\hline 24 I easily adapt to new situations. & .334 & .697 & .169 & .059 & .266 \\
\hline 25 It's easy for me to make other people laugh. & .327 & .635 & .115 & .173 & .110 \\
\hline \multicolumn{6}{|l|}{ Factor 3 - Family support } \\
\hline 30 In our family we are loyal to each other. & .100 & .118 & .831 & .193 & .158 \\
\hline 31 In our family we enjoy doing activities together. & .142 & .198 & .777 & .285 & .166 \\
\hline 28 I have a good relationship with my family. & .261 & .166 & .758 & .259 & .023 \\
\hline 33 In our family we agree on what we consider important in life. & .194 & .094 & .709 & .341 & .233 \\
\hline $\begin{array}{l}32 \text { Even in difficult times, our family has an optimistic attitude towards } \\
\text { the future. }\end{array}$ & .320 & .162 & .603 & .290 & .129 \\
\hline \multicolumn{6}{|l|}{ Factor 4 - Social support } \\
\hline 34 I have friends /relatives who really care about me. & .143 & .119 & .357 & .814 & .079 \\
\hline 35 I have friends / relatives who support me. & .218 & .076 & .337 & .802 & .076 \\
\hline 36 I always have someone who can help me when I need it. & .189 & .171 & .199 & .798 & .081 \\
\hline 37 I have friends / relatives who encourage me. & .102 & .140 & .311 & .735 & .294 \\
\hline 38 I have friends / relatives who value my skills. & .218 & .091 & .356 & .727 & .229 \\
\hline \multicolumn{6}{|l|}{ Factor 5 - Structure } \\
\hline 41 I prefer to plan my activities. & .298 & .166 & .059 & .107 & .742 \\
\hline 39 Rules and routine make my life easier. & .250 & .187 & .131 & .283 & .733 \\
\hline 40 I maintain my routine even in difficult times. & .307 & .203 & .030 & .154 & .721 \\
\hline 42 I work better when I have goals. & .349 & .063 & .217 & .007 & .641 \\
\hline 43 I'm good at organizing my time. & .210 & .155 & .161 & .142 & .600 \\
\hline
\end{tabular}


Table 2

\begin{tabular}{lccccc} 
Variance, means and Cronbach's alpha coefficients of the final version of the instrument $(n=280)$ \\
\hline \multirow{2}{*}{ Factors } & $\begin{array}{c}\text { Number of items } \\
\text { Explained variance }\end{array}$ & Mean & Variance & Cronbach's alpha \\
& 18 & $63.6 \%$ & 134.9 & 378.30 & .964 \\
\hline Strength and self-confidence & 8 & $20.34 \%$ & 58.50 & 91.90 & .945 \\
Social competence & 5 & $13.97 \%$ & 25.74 & 24.87 & .930 \\
Family support & 5 & $10.58 \%$ & 17.14 & 9.81 & .903 \\
Social support & 5 & $10.21 \%$ & 17.72 & 8.65 & .932 \\
Structure & $8.55 \%$ & 15.84 & 9.70 & .853 \\
\hline
\end{tabular}

A summary of the reliability analysis by factors is shown in Table 2. The final instrument with 41 items had an overall internal consistency (Cronbach's alpha) of .96, accounting for $63.6 \%$ of the total variance, while consistency by subscales ranged from .85 to .95 , with an overall average of $134.90 \pm 19.45$. Bartlett's sphericity test yielded a value of $9208.06(\mathrm{p} \leq .001)$ indicating non-identity of the correlation matrix, while the Kaiser-Meyer-Olkin index (.942) indicated sampling adequacy, because it is close to 1 .

\section{Confirmatory analysis}

The fit of the five-factor model obtained through the exploratory analysis was evaluated through a confirmatory factor analysis (CFA) using the maximum likelihood method, with the following steps:

1. Identification of the model: For the model analyzed, there were 46 endogenous variables (41 involving measures and five involving structures) out of a total of 93 variables. There were 52 non-observed variables (total parameters to be estimated by the model), 46 of which were exogenous (41 measurement errors, five residual errors), out of a total of non-redundant elements of the matrix equal to 1081 . Since the parameters to be estimated are clearly lower than the total number of non-redundant elements in the matrix, we can say that the model is over-identified and can be identified. Since there are no correlations between the residuals, it is a recursive model.

2. Specification of the model: Based on the exploratory analysis of reliability and the factor analysis previously presented, a model for Figure 1 was designed whereby the circumferences or ovals represent latent variables and the rectangles represent the observable variables. Measurement and residual errors are shown as smaller ovals.

3. Estimate of parameters: The AMOS program was asked to apply the maximum likelihood method, with standardized estimators, $\mathrm{R}^{2}$ estimator (multiple squared correlations), covariances of the estimators, indices to be modified and critical proportions for the differences.
4. For the evaluation of fit (the sample exceeds $n=200$ ), as a first step, all the results were examined to ensure that the estimated coefficients did not exceed the acceptable limits (that there were no negative or insignificant error variances, standardized coefficients over 1, or excessively high standard errors related to an estimated coefficient). No collinearity was observed in the variables measured, since the correlations were less than .3 (Kline, 2005) or extreme or univariate or multivariate scores (George \& Mailery, 2010). Moreover, excellent asymmetry was observed in all the variables (values not over $\pm 1.00),( \pm 10$ points) except in the Family Support and Social Support variables, yet still within adequate parameters (Tabachnick \& Fidell, 2001).

5. Table 3 shows that as regards the absolute measures of overall adjustment, the chi square value was $1755.32(p=\leq .001,766 \mathrm{gl})$, while the chi square ratio and degrees of freedom $(\mathrm{CMIN} / \mathrm{DF}=$ 2.29 ) is excellent, indicating that mistakes in the variances and covariances of the model are null and adjusted to samples of over 200 data as recommended by the experts (Byrne, 2010).

The comparative measures of global adjustment, and the comparative fit index (CFI), are very close to the ideal $(\mathrm{CFI}=.88)$, as is the Tucker-Lewis index, which takes into account the complexity of the model $(\mathrm{TLI}=.87)$, indicating an acceptable fit with the data, since at least $87 \%$ of the covariance in the data can be reproduced by the model (Byrne, 2010).

Since the parsimony indices $(\mathrm{PCFI}=.823)$ are very close to the optimal value (.900), the model can be described as complex - (Hu \& Bentler, 1998), as the goodness of fit statistics show to an acceptable extent (GFI $=.769$, AGFI $=.740$, PGFI $=.684)$, in addition to the Root Mean Square Error of Approximation $\left(\mathrm{RMSEA}=.068, \mathrm{CI}_{95 \%}=\right.$ $.064-.072$ ), which penalizes the increase in the complexity of the model and indicates an excellent fit with the data, since it is less than .08 and is confirmed by the value in the Residual Mean Error $(\mathrm{RMR}=.031)$, since this fulfils the requirement of being below the threshold value, indicating nearly zero error and an almost perfect fit (less than .05) (Byrne, 2010). 


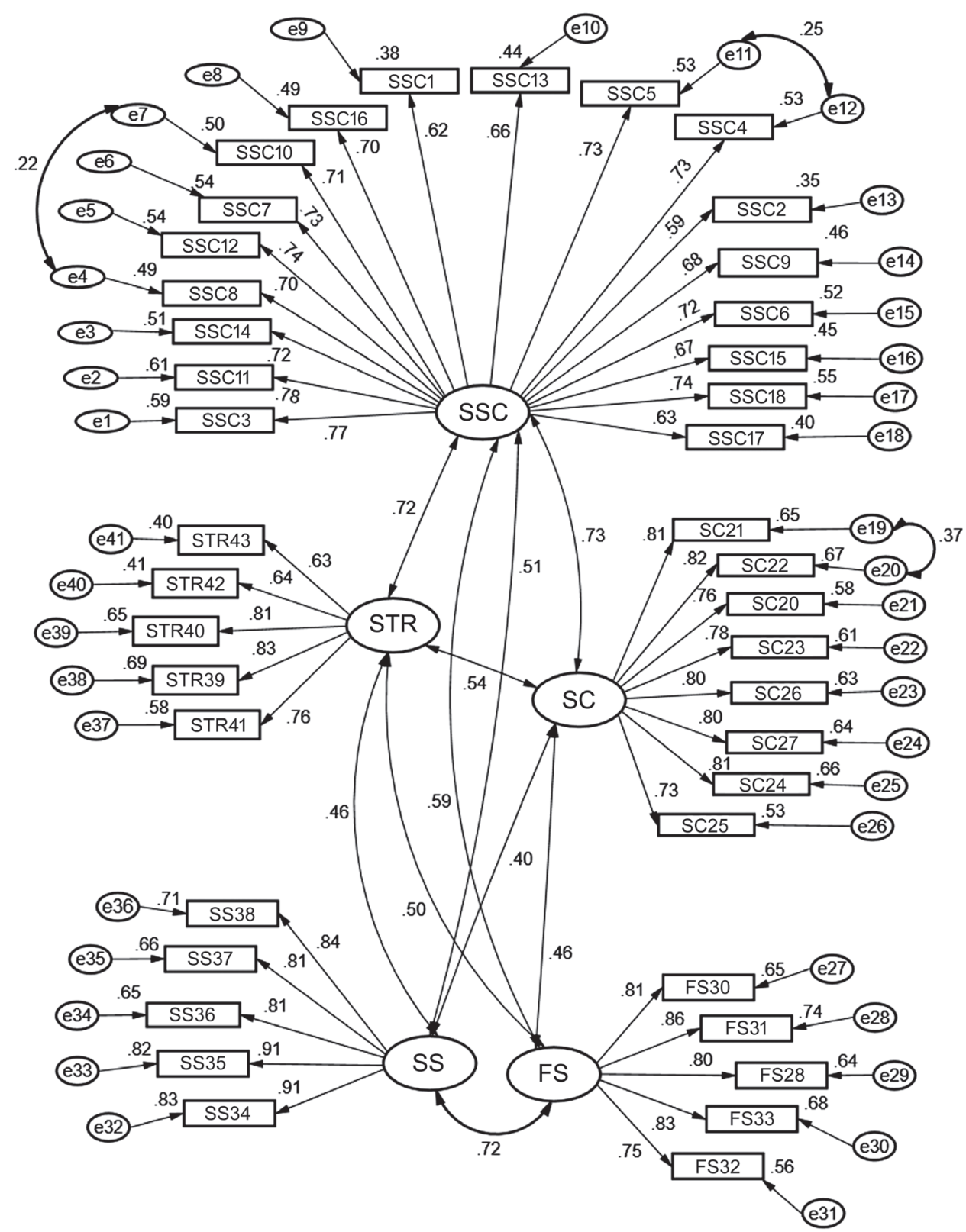

Figure 1. Confirmatory model of five resilience factors in Mexican kidney patients $(n=280)$. Chi square $=$ $1755.32,766 \mathrm{gl}, p \leq .001 ; \mathrm{CMIN} / \mathrm{gl}=2.292 ; \mathrm{RMR}=.031 ; \mathrm{GFI}=.769 ; \mathrm{CFI}=.881 ; \mathrm{RMSEA}=.068(.064-.072)$.

Table 3

Goodness-of-fit indices of the confirmatory model resulting from 5 factors in kidney patients $(n=280)$

\begin{tabular}{|c|c|c|c|}
\hline Statistics & Desirable criterion & Value in the present study & Interpretation \\
\hline Absolute fit X²/gl (CMIN/gl) & Less than 2 or 3 & $1755.32 / 766 \mathrm{gl}=2.292$ & $\begin{array}{l}\text { The errors of the model are null with the } \\
\text { sample used and the absolute fit is excellent }\end{array}$ \\
\hline Goodness of fit index (GFI) & $>.90$ Preferential > .95 & $\mathrm{GFI}=.769$ & Good fit \\
\hline $\begin{array}{l}\text { Comparative goodness of fit index } \\
\text { (CFI) }\end{array}$ & $>.90$ Preferential > .95 & $\mathrm{CFI}=.881$ & Acceptable comparative fit \\
\hline Root Mean Square Residual (RMR) & Near zero & $\mathrm{RMR}=.031$ & $\begin{array}{l}\text { Model error close to zero, almost perfect fit } \\
\text { of model to data }\end{array}$ \\
\hline $\begin{array}{l}\text { Root mean square error of approx- } \\
\text { imation }\end{array}$ & Less than .08 , close to zero & RMSEA $=.068(.064-.072)$ & $\begin{array}{l}\text { Model error close to zero, almost perfect fit } \\
\text { of model to data }\end{array}$ \\
\hline
\end{tabular}


Table 4

Correlation between dimensions of resilience and depression and anxiety symptoms and distorted thoughts $(n=280)$

\begin{tabular}{|c|c|c|c|c|c|c|}
\hline \multirow[b]{2}{*}{ Psychological variables } & \multicolumn{5}{|c|}{ Resilience factors } & \multirow{2}{*}{$\begin{array}{c}\text { Total } \\
\text { resilience }\end{array}$} \\
\hline & SSC & $S C$ & $F S$ & SS & $S$ & \\
\hline Social competence (SC) & $.68^{* *}$ & & & & & \\
\hline Family support (FS) & $.60^{* *}$ & $.39^{* *}$ & & & & \\
\hline Social support (SS) & $.51^{* *}$ & $.38^{* *}$ & $.65^{\star *}$ & & & \\
\hline Structure (S) & $.68^{* *}$ & $.47^{* *}$ & $.47^{* *}$ & $.44^{* *}$ & & \\
\hline Total resilience & $.94^{* *}$ & $.78^{* *}$ & $.74^{\star *}$ & $.67^{* *}$ & $.75^{\star *}$ & \\
\hline \multicolumn{7}{|l|}{ Anxiety Symptoms } \\
\hline Total score & $-.49^{* *}$ & $-.45^{\star *}$ & $-.35^{\star *}$ & $-.31^{* *}$ & $-.32^{\star *}$ & $-.51^{* *}$ \\
\hline Somatic anxiety & $-.50^{* *}$ & $-.44^{* *}$ & $-.32^{\star *}$ & $-.28^{* *}$ & $-.33^{\star *}$ & $-.50^{\star *}$ \\
\hline Cognitive anxiety & $-.41^{* *}$ & $-.39^{\star *}$ & $-.35^{\star *}$ & $-.30^{* *}$ & $-.23^{\star *}$ & $-.44^{\star *}$ \\
\hline \multicolumn{7}{|l|}{ Depression symptoms } \\
\hline Total score & $-.58^{* *}$ & $-.41^{* *}$ & $-.42^{* *}$ & $-.28^{* *}$ & $-.40^{* *}$ & $-.56^{\star *}$ \\
\hline Somatic depression & $-.57^{* *}$ & $-.40^{* *}$ & $-.38^{* *}$ & $-.26^{* *}$ & $-.41^{* *}$ & $-.55^{\star *}$ \\
\hline Cognitive depression & $-.52^{* *}$ & $-.38^{* *}$ & $-.42^{* *}$ & $-.26^{* *}$ & $-.31^{* *}$ & $-.51^{* *}$ \\
\hline \multicolumn{7}{|l|}{ Distorted thoughts } \\
\hline Total score & $-.37^{* *}$ & $-.27^{* *}$ & $-.28^{* *}$ & $-.25^{\star *}$ & $-.20^{\star *}$ & $-.36^{* *}$ \\
\hline Catastrophism & $-.45^{* *}$ & $-.33^{* *}$ & $-.33^{* *}$ & $-.27^{* *}$ & $-.28^{* *}$ & $-.43^{* *}$ \\
\hline Dichotomous thinking & $-.23^{\star *}$ & $-.15^{\star}$ & $-.22^{\star *}$ & $-.16^{*}$ & -.07 & $-.22^{\star *}$ \\
\hline Intrinsic perfectionism & $-.14^{*}$ & -.06 & $-.21^{\star \star}$ & $-.16^{*}$ & -.02 & $-.15^{\star}$ \\
\hline Extrinsic perfectionism & $-.23^{\star *}$ & $-.14^{*}$ & $-.30^{\star *}$ & $-.22^{\star *}$ & -.10 & $-.24^{\star *}$ \\
\hline Perfectionism (Total score) & $-.17^{* *}$ & -.09 & $-.24^{* \star}$ & $-.20^{* *}$ & -.05 & $-.18^{* *}$ \\
\hline Negative self-labeling & $-.25^{\star \star}$ & $-.14^{*}$ & $-.24^{* *}$ & $-.20^{* *}$ & -.09 & $-.24^{\star *}$ \\
\hline
\end{tabular}

Notes: FS = Family support; SS = Social support; SC = Social competence; $\mathrm{S}=$ Structure; SSC = Strength and self-confidence; ${ }^{*} p<.05$ (bilateral), ${ }^{* *} p<.001$ (bilateral).

\section{Correlation of resilience with other psychological variables}

The five factors correlated positively with each other, and negatively with anxiety and depression symptoms and distorted thoughts (Table 4). These correlations were significant $(p<.05)$ between the total resilience score and the total and subscale scores of depression and anxiety symptoms and distorted thoughts. All resilience factors correlate with the cognitive and somatic subscales of depression and anxiety, and there was correlation between resilience factors and most of the distorted thoughts subscales.

\section{DISCUSSION AND CONCLUSION}

The results of this study show that the instrument evaluated is reliable and valid for measuring resilience in patients with CKD. This specific version retained 41 of the 43 original items, with the same number of original subscales, all associated with depression and anxiety symptoms as well as distorted thoughts. In the confirmatory analysis, a theoretical structural model was obtained, which acceptably fits the complexity of the data in this specific sample with kidney patients, according to the most important reliabili- ty indices shown and suggested by experts (Byrne, 2010; George et al., 2010; Hu \& Bentler, 1998; Kline, 2005; Tabachnick et al., 2001). The model contains five factors with a strong association between them, as the exploratory analysis showed, which allows us to recommend this instrument to assess resilience in patients with chronic kidney insufficiency (CKI). The most powerful indicators of the fit of the model's structure (CFI, RMR, and RMSEA) suggest that it is a balanced, parsimonious model (Ullman, 2006).

This adjusted version for measuring psychological resilience could be used to complement information on psychological aspects of kidney patients. The psychological vulnerability of these patients to the disease could be detected by the factorial components of the adapted resilience scale. In future studies, the clinical usefulness of resilience could be evaluated as part of new strategies to reduce dysfunctional behaviors (e.g., dropping out of treatments) and the negative physical (e.g., impaired health), mental (depression and anxiety) and social consequences (such as social abandonment and functional dependence).

This psychological instrument evaluates resilience in patients with CKD, which would enable new studies to understand, analyze, and explore how they use their internal and external resources to positively cope with illness, because some previous studies mainly focus on detecting the 
negative effects of the disease (Cukor et al., 2009; Dobrof, Dolinko, Lichtiger, Uribarri, \& Epstein, 2002; Elliott, Gessert, Larson, \& Russ, 2014; Ma, Chang, Liu, Hsieh et al., 2013; Nicholas, Picone, \& Selkirk, 2011; Shidler, Peterson, \& Kimmel, 1998; Tong et al., 2014; Wick, Bauer, Malessa, Settmacher, Strauss, 2015).

This study confirms the relationship between distorted thoughts and depression and anxiety symptoms (Lerma et al., 2012) and is now combined with the measurement of resilience in kidney patients. We regard these associations as empirical evidence that support the development of cognitive-behavioral strategies combined with these variables in order to impact psychological and clinical aspects in this population (Tong, Lesmana, Johnson, Wong et al., 2013). For example, the reliable quantitative evaluation of resilience in these patients would make it possible to evaluate the effectiveness of psychological interventions that include resilience to reduce depression, anxiety, and the presence of distorted thoughts, all of which reduce the quality of life (Cukor, 2007; Cukor et al., 2009; Lerma et al, 2017; Shidler et al., 1998). Likewise, this validated instrument would make it possible to study the relationship between resilience and other variables such as family ethnicity (White et al., 2002), time of diagnosis (Quiceno \& Vinaccia, 2012), perception of disease (Schipper et al., 2014), social support, devaluation, self-efficacy, and self-esteem (Tong et al., 2013) so that they can be explored in studies of diagnosis, prognosis, and psychological intervention.

Although the constructs of resilience and depression and anxiety belong to different theoretical models -with the former coming from a positive psychosocial approach (Cabanyes Truffino, 2010; Rodriguez-Piaggio, 2009; Vinaccia et al., 2011) which attempts to identify protective or risk elements or factors-, whereas depression and anxiety are more closely linked to the medical risk model (Cukor et al., 2009; Ma et al., 2013; Wick et al., 2015) (for example, age, sex, education, negative attitudes, or perception of disease) - the relationship found between them in our research suggests the need for new studies to explore and empirically test the mechanisms that explain this relationship from the point of view of their pertinence and clinical interest for measuring the quality of life in patients with CKD. The role of psychological resilience in these patients, as well as the impact it has on the emotional state and quality of life has barely been researched. The instrument validated in the present study could be used to evaluate whether low resilience in a population predisposes it to greater hypersensitivity and inadequate responses to the presence of adverse symptoms of the disease (Cukor et al., 2007; Cukor et al., 2009; Lerma et al., 2017; Shidler et al., 1998) (e.g., hypotension during hemodialysis).

As suggested by previous research (Miranda-Zapata, Riquelme-Mella, Cifuentes-Cid, \& Riquelme-Bravo, 2014) our study was conducted with a multicentric sample of pa- tients with CKD, from secondary and tertiary level hospitals (in kidney substitution treatment), which strengthens our confidence in the external validity of the scale used. However, more extensive, heterogeneous studies are required nationwide to increase the generalization of the results that will facilitate the construction of standardized scales of this instrument. The present study did not evaluate the associations between resilience and sociodemographic and clinical variables of patients, which is undoubtedly an important research topic. However, the evaluation of these associations goes beyond the scope of the objectives of this paper and future studies are required to address the issue comprehensively and sufficiently. Another limitation of the study is that it failed to evaluate the cognitive capacity of respondents, one of the factors that can be altered by disease or age. Lastly, the results of the validation, including the structural equations model obtained in the confirmatory analysis, are applicable to patients with CKD only. Other studies must be undertaken to evaluate this scale in patients with other chronic diseases (such as diabetes mellitus) where it is known that there is also high comorbidity of anxiety and depression symptoms.

\section{Funding}

None.

\section{Conflict of interests}

The authors declare they have no conflict of interests.

\section{REFERENCES}

Arbuckle, J. (2012). IBM SPSS AMOS 21 User's Guide. Armonk, NY, USA: IBM Corporation.

Beck, A. T., Epstein, N., Brown, G., \& Steer, R. A. (1988). An inventory for measuring clinical anxiety: Psychometric properties. Journal of Consulting and Clinical Psychology, 56(6), 893-897. doi: 10.1037/0022-006X.56.6.893

Beck, A. T. (2006). Inventario de Depresión de Beck (BDI-II1). USA: The Psychological Corporation, Eds.

Byrne, B. (2010). Structural equation modeling with AMOS: Basic Concepts, Applications, and Programming. New York, USA: Routledge.

Cabanyes Truffino, J. (2010). Resiliencia: una aproximación al concepto. Revista de Psiquiatría y Salud Mental, 3(04), 145-151. doi: 10.1016/j.rpsm.2010.09.003

Cukor, D. (2007). Use of CBT to treat depression among patients on hemodialysis. Psychiatric Services, 58(5), 711-712. doi: 10.1176/appi.ps.58.5.711

Cukor, D., Cohen, S. D., Peterson, R. A., \& Kimmel, P. L. (2007). Psychosocial aspects of chronic disease: ESRD as a paradigmatic illness. Journal of the American Society of Nephrology, 18(12), 3042-3055. doi: 10.1681/ASN.2007030345

Cukor, D., Coplan, J., Brown, C., Friedman, S., Newville, H., Safier, M., ... \& Kimmel, P. L. (2008). Anxiety disorders in adults treated by hemodialysis: a single-center study. American Journal of Kidney Diseases, 52(1), 128-136. doi: 10.1053/j.ajkd.2008.02.300

Cukor, D., Rosenthal, D. S., Jindal, R. M., Brown, C. D., \& Kimmel, P. L. (2009). Depression is an important contributor to low medication adherence in hemodialyzed patients and transplant recipients. Kidney International, 75(11), 1223-1229. doi: 10.1038/ki.2009.51

Dobrof, J., Dolinko, A., Lichtiger, E., Uribarri, J., \& Epstein, I. (2002). Dialysis patient characteristics and outcomes: the complexity of social work practice with the end stage renal disease population. Soc Work Health Care, 33(3-4), 105-128. doi: 10.1300/J010v33n03_08 
Elliott, B. A., Gessert, C. E., Larson, P. M., \& Russ, T. E. (2014). Shifting responses in quality of life: People living with dialysis. Qual Life Res, 23(5), 1497-1504. doi: 10.1007/s11136-013-0600-9

George, D. \& Mailery, P. (Ed.) (2010). Using SPSS for Windows step by step: a simple guide and reference. Boston, MA: Aliyn \& Bacon.

Hu, L. t., \& Bentler, P. M. (1998). Fit indices in covariance structure modeling: Sensitivity to underparameterized model misspecification. Psychological Methods, 3(4), 424-453. doi: 10.1037//1082-989X.3.4.424

Kline, R. (2005). Principies and practice of structural equation modeling. New York, USA: The Guilford Press.

Lerma, A., Perez-Grovas, H., Bermudez, L., Peralta-Pedrero, M., Robles-García, R., \& Lerma, C. (2017). Brief cognitive-behavioral intervention for depression and anxiety symptoms improve quality of life among chronic hemodialysis patients. Psychology and Psychotherapy: Theory, Research and Practice, 90(1), 105123. doi: 10.1111/papt.12098

Lerma, A., Salazar, E., Perez-Grovas, H., Bermudez, L., Gutierrez, D., ReyesLagunes, I., ... \& Lerma, C. (2012). Desarrollo y validación de un instrumento para la evaluación de distorsiones cognitivas en pacientes con insuficiencia renal cronica terminal. Salud Mental, 35(3), 189-194. Retrieved from: http:// revistasaludmental.mx/index.php/salud_mental/article/view/1471/1469

Ma, L. C., Chang, H. J., Liu, Y. M., Hsieh, H. L., Lo, L., .. \& Lu, K. C. (2013). The relationship between health-promoting behaviors and resilience in patients with chronic kidney disease. Scientific World Journal, 124973. doi: 10.1155/2013/124973

Miranda-Zapata, E., Riquelme-Mella, E., Cifuentes-Cid, H., \& Riquelme-Bravo, P. (2014). Análisis factorial confirmatorio de la Escala de habilidades sociales en universitarios chilenos. Revista Latinoamericana de Psicología, 46(2), 73-82. doi: 10.1016/S0120-0534(14)70010-X

Nicholas, D. B., Picone, G., \& Selkirk, E. K. (2011). The lived experiences of children and adolescents with end-stage renal disease. Qualitative Health Research, 21(2), 162-173. doi: 10.1177/1049732310382789

Palomar-Lever, J. \& Gómez-Valdéz, N. E. (2010). Desarrollo de una escala de medición de resiliencia con mexicanos (RESI-M). Interdisciplinaria, 27(1). Retrieved from: http://www.redalyc.org/articulo.oa?id=18014748002

Quiceno, J., \& Vinaccia, S. (2012). Resiliencia y características sociodemográficas en enfermos crónicos. Psicología desde el Caribe, 29(1), 87-104. Retrieved from: http://www.redalyc.org/articulo.oa?id=21323171006

Robles, R., Varela, R., Jurado, S., \& Páez, F. (2001). Versión mexicana del Inventario de Ansiedad de Beck: propiedades psicométricas. Revista Mexicana de Psicología, 18(2), 211-218.
Rodriguez-Piaggio, A. (2009). Resiliencia. Revista Psicopedagogia, 26(80), 291-302. Retrieved from: http://pepsic.bvsalud.org/scielo.php?script=sci abstract\&pid=S0103-84862009000200014\&lng=pt\&nrm=iso\&tlng=es

Schipper, K., Abma, T. A., Koops, C., Bakker, I., Sanderman, R., \& Schroevers, M. J. (2014). Sweet and sour after renal transplantation: A qualitative study about the positive and negative consequences of renal transplantation. British Journal of Health Psychology, 19(3), 580-591. doi: 10.1111/bjhp.12057

Shidler, N. R., Peterson, R. A., \& Kimmel, P. L. (1998). Quality of life and psychosocial relationships in patients with chronic renal insufficiency. American Journal of Kidney Diseases, 32(4), 557-566. doi: 10.1016/S0272-6386(98)70017-4

Tabachnick, B., \& Fidell, L. (2001). Using multivariate statistics. New York, USA: Harper \& Row.

Tong, A., Cheung, K. L., Nair, S. S., Kurella, T. M., Craig, J. C., \& Winkelmayer, W. C. (2014). Thematic synthesis of qualitative studies on patient and caregiver perspectives on end-of-life care in CKD. American Journal of Kidney Diseases, 63(6), 913-927. doi: 10.1053/j.ajkd.2013.11.017

Tong, A., Lesmana, B., Johnson, D. W., Wong, G., Campbell, D., \& Craig, J. C. (2013). The perspectives of adults living with peritoneal dialysis: thematic synthesis of qualitative studies. American Journal of Kidney Diseases, 61(6), 873-888. doi: 10.1053/j.ajkd.2012.08.045

Torres-Castillo, M., Hernández-Malpica, E., \& Ortega-Soto, H. (2012). Validez y reproducibilidad del Inventario para Depresión de Beck en un hospital de cardiología. Salud Mental, 14(2), 1-6.

Ullman, J. B. (2006). Structural equation modeling: Reviewing the basics and moving forward. Journal of Personality Assessment, 87(1), 35-50. doi: 10.1207/ s15327752jpa8701_03

Vinaccia, S. \& Quiceno, J. (2011). Resiliencia y calidad de vida relacionada con la salud en pacientes con insuficiencia renal crónica. Revista Argentina de Clínica Psicológica, $X X(3), 201-211$. Retrieved from: http://www.redalyc.org/articulo. oa? $\mathrm{id}=281922826002$

White, N., Bichter, J., Koeckeritz, J., Lee, Y. A., \& Munch, K. L. (2002). A crosscultural comparison of family resiliency in hemodialysis patients. Journal of Transcultural Nursing, 13(3), 218-227. doi: 10.1177/10459602013003011

Wick, K., Bauer, S., Malessa, C., Settmacher, U., \& Strauss, B. (2015). Relationship between stress and resources in patients waiting for organ transplantation: Comparison of patients with renal and liver insufficiency. Psychother Psychosom Med Psychol, 65(8), 311-320. doi: 10.1055/s-0035-1549999 